\title{
The interplay between household food security and wellbeing among small-scale farmers in the context of rapid agrarian change in India
}

Kirit Patel $^{1^{*}}$, Hom Gartaula ${ }^{1,2}$, Derek Johnson ${ }^{2}$ and M. Karthikeyan ${ }^{3}$

\begin{abstract}
Background: Small-scale agriculture, government entitlements, and livelihood opportunities offered by rapid economic growth shape the food security and wellbeing of people in rural India. This paper analyses this ongoing process of agrarian development from the perspective of three major approaches: the food availability approach, the entitlement and livelihood approach, and food sovereignty. We draw on quantitative and qualitative data collected from 68 households in rural Tamil Nadu on landholding and management, farm diversity, agricultural production, food availability, off-farm employment, rural out-migration, objective and subjective wellbeing, and socioeconomic and demographic profile of respondents.

Results: Rural households were classified in four categories, based on their engagement in agriculture and off-farm employment, to understand the interplay between food sufficiency and wellbeing. The households solely based on small-scale agriculture were found to have higher food sufficiency, landholding, and crop diversity, but lower monthly income and wellbeing. The households that were engaged in off-farm employment in addition to agriculture were found to have lower food sufficiency, landholding, and crop diversity, yet they exhibited better wellbeing and higher income. The landless households, which were primarily engaged in off-farm labour, work in distant markets had higher income than households solely engaged in farming. However, they had the lowest wellbeing index among all household types. The findings indicated that the impacts of women's participation in local or distant employment schemes on household food security and wellbeing were complex and shaped by the household's engagement in agriculture and their aspirations for a better quality of life.
\end{abstract}

Conclusions: None of the three food security approaches provides a fully satisfactory basis for interventions aimed at enhancing the capacity of small and marginal farmers to achieve food security and meet their aspirations for wellbeing in the research area, although the entitlements and livelihoods approach has had a significant impact on local possibilities for livelihoods diversification. The study demonstrates that the interaction between food security and the subjective wellbeing of farmers is complex and shaped by the productivity of small-scale agriculture and livelihood aspirations of farm households.

Keywords: Agrarian change, Food security, Social wellbeing, Food sovereignty, Tamil Nadu, India

\footnotetext{
*Correspondence: k.patel@uwinnipeg.ca

${ }^{1}$ International Development Studies, Menno Simons College, Canadian

Mennonite University, 520 Portage Avenue, Winnipeg, MB R3C 0G2,

Canada

Full list of author information is available at the end of the article
} 


\section{Background}

In recent decades, there has been significant economic growth in India, including substantial increases in gross domestic product (GDP), per capita income, and total food grain production [1]. In 2010, India was the world's 20th largest goods exporter and the seventh largest services exporter [2]. Yet, despite boasting to be the thirdlargest economy in the world in purchasing power parity terms [3], India ranks 65th on the Global Hunger Index [4]. Indian statistics on child mortality, malnutrition, stunting and underweight are comparable to levels seen in many developing nations experiencing low economic growth. In the 100 poorest districts of India, $42 \%$ of children under the age of five are underweight, and $59 \%$ are stunted [5]. In the period between 1983 and 2009, although a $40 \%$ increase in monthly per capita expenditure occurred, the per capita caloric intake in rural India declined by $16 \%$ [6]. These statistics call into question the oft-argued trickledown effect of rapid economic growth on food consumption, public health and people's overall wellbeing.

Rapid economic growth has also led to significant agrarian development. It has allowed the penetration of market and other forces of capitalism into the agricultural production system, leading to advances in production techniques, along with the reorganization of landholdings, rural labour and distribution of agricultural outputs [7]. The importance of agriculture has declined as other sectors of the economy have grown and as the share of food and agricultural raw materials supplied by the global market has increased. Productivity gains within India's own agriculture are thus now relatively less of a development priority for the country [8]. The agrarian transition caused by rapid economic growth calls for an impact assessment of the various measures employed by the state and other development actors for ensuring food security, livelihood options and the wellbeing of people.

The literature review presented in this paper provides a historical overview of three approaches to food security employed in India. This review recognizes the need for examining the impacts of food security approaches on the objective and subjective wellbeing of people. Following the review section, we report on an empirical study of objective and subjective wellbeing conducted in four villages of Anchetty Panchayat in Tamil Nadu, India. This Panchayat has seen significant agrarian development over the last two decades, including interventions of state and other development actors to support food security, small-scale agriculture, employment and livelihood diversification. The findings reveal that fragmented and inadequate landholdings, combined with better income opportunities in urban areas, are driving people to seek non-farm livelihood options either in their villages or in urban centres within and outside the state. The results demonstrate the compounding effects of out-migration from rural areas on small-scale agriculture and on food and livelihood security. Out-migrant households were found to have fewer cattle and tended to rent out their land, lowering soil fertility. Women in these households had unsustainable workloads, which reduced their subjective attachment to agriculture. These ecological factors and subjective experiences are crucial contextual aspects that govern food security over time. However, the existing food security approaches treat local actors as passive victims, thus underplaying ecological, economic and sociocultural contexts. It is clear that the development scholarship needs to address factors of subjective wellbeing, intra-household gender relations and agency, as well as the ecological, economic and structural contexts that shape small and marginal farmers' response to agrarian change. Doing so will lead to better understanding of the process of change in agrarian economies, how rural populations adapt in order to best satisfy their need for food security and improved wellbeing, and how development interventions can best be targeted for poverty alleviation under these conditions.

\section{Insights and shortcomings of three food security approaches}

Food security: an overview of concepts, approaches and their relevance

The concept of food security was first introduced to the global community at the World Food Conference organized by the United Nations General Assembly in 1974. Since this time, an intense debate has evolved surrounding the conceptualization and measurement of food security. ${ }^{1}$ In the 1970 s, food security was defined by fluctuations in food availability as well as by the instability of food grain prices [11]. Consequently, it was thought that an adequate global food supply was needed at all times to sustain a steady expansion of food consumption, as well as to offset fluctuations in food grain prices [12]. However, the subsequent work of several scholars [13-15] provided a multi-dimensional understanding of food insecurity and poverty. These scholars argued that unequal access to and distribution of food-due to a lack of economic resources and capabilities of individuals-are equally important aspects of food security. This led to a distinction between the ability of the state to ensure a constant supply of food at the national level, and the capability of individuals or households to access available food.

The classical understanding of food security defined in the 1970s was reassessed at the 1996 World Food Summit

\footnotetext{
${ }^{1}$ Thus far, approximately 200 definitions and 450 indicators of food security have been presented in the food security literature. For details, refer to Mechlem [9] and Maxwell [10].
} 
in order to reflect the importance of distribution, quality of food and equality of economic access. The Summit helped to normalize the multi-dimensional meaning of food security, stating that food security exists when all people, at all times, have physical and economic access to sufficient, safe and nutritious food to meet their dietary needs and food preferences for an active and healthy life [16]. Though scholars have continued to reinterpret and redefine the concept of food security, this definition has remained a pillar in food security studies.

The concept of food security has also been deeply enriched by scholarly work on human rights, sustainable livelihoods, women's concerns and gender issues in development, food quality and safety, organic agriculture and sustainable environments. This work transformed the concept of food security from a macroeconomic analysis of food supply to a microeconomic or intrahousehold level understanding of food distribution that takes into account gender equality, the environment, and human aspirations and dignity. From this understanding, a rights-based approach to food security evolved, which later became the food sovereignty movement. While other food security movements tended to view small farmers and peasantry as victims of food deficit, the food sovereignty movement argued that small farmers, artisanal fisher-folk, pastoralists and indigenous people were capable of producing enough food for their communities and feeding the world in a sustainable and healthy way, given appropriate rights to land, water and seed, and control over the food market [17].

Food security is a vital component of human development and wellbeing, and thus must be safeguarded and sustained by states, communities and individuals. An examination of literature commencing with the start of the food aid era in the 1940s indicates a range of interventions and programmes for addressing global food security. Yaro [18] classifies these interventions into three major approaches: the food availability approach, the livelihood and entitlement approach and the food sovereignty approach. These approaches have been employed by support-led food security measures through public institutions or by growth-led security measures through market institutions, depending on the ideology and resources available to various development actors [14]. The three approaches differ in their strategic focus, ranging from the means of attaining food security to the ends, or outcome, of being food-secure. Using examples of food security interventions in India, the remainder of this literature section illustrates the differences in conceptualization, implementation, actors and driving forces, potential outcomes and impacts of the three food security approaches described by Yaro [18].

\section{The food availability approach}

The food availability approach cites a lack of food as the primary cause of food insecurity, and thus emphasizes an increase in the production and storage of food grains at both regional and national levels of government [19]. An increased investment in technological advancements to promote intensive agriculture-commonly referred to as the green revolution-demonstrates this support-led intervention. The green revolution led to a profound increase in food grain production in the early 1970s and was responsible for increasing the calorie supply in India from $2396 \mathrm{kcal} /$ day/capita in 1975 to $2589 \mathrm{kcal} /$ day/capita in 1985 [20]. In 1971, the Indian state created a new National Productioncum-Distribution System for distributing surplus food grains from regions partaking in the green revolution to regions experiencing food deficits throughout the country. Rather than ensuring equitable access to food and nutrition security for the poor, this state-led distribution scheme sought to provide guaranteed minimum prices to farmers of well-endowed green revolution regions. During the post-structural adjustment era of the 1990s, the neoliberal state imposed cuts in public sector expenditure and encouraged market or growthled initiatives for developing agricultural technology to promote production. These initiatives encouraged the role of the private sector in developing new seeds, using advanced biotechnological tools known as gene revolutions, and in providing other agricultural inputs and services to farmers.

Although the food availability approach succeeded in increasing the food supply in India, this paradigm has been criticized for not addressing matters such as inequality of access to agricultural technologies, land and water distribution, and environmental sustainability [21]. The inequality spurred by the green revolution created significant social strains [22]. Furthermore, it resulted in an intensification of agriculture, which led to a decline in agricultural biodiversity, groundwater levels, soil fertility and productivity. According to Drèze and Sen [14], food security is affected by the mode of production as well by as the structure of the agrarian economy in which growth of the agricultural sector occurs. Fine [23] observes that the food availability approach overemphasized the need for an aggregate supply of food, instead of considering individual or household-level preferences and strategies for accessing food. For instance, the subsidized distribution of rice and wheat, supplied by green revolution regions, has grossly undermined the nutritional and cultural preferences of the people in food recipient regions. This has contributed to malnutrition and a decline in dietary diversity among the poor in India [24]. 


\section{The entitlement and livelihood approach}

Following the seminal work of Amartya Sen and other scholars in the late 1980s, the global debate on food security shifted from a focus on supply to a focus on accessibility, vulnerability and entitlements of the poor to satisfy food demand at household and individual levels. Food security measures under the entitlement and livelihood approach are premised on the understanding that hunger and malnutrition are caused by a lack of purchasing power of the poor to meet their food requirements [13]. If the poor could gain access to income or the means to earn a livelihood, they would purchase food available from local markets. It is assumed, therefore, that markets will supply food-either locally or from other regions with surplus production-if people have purchasing power and an assured access to livelihood. Thus, the entitlement and livelihood approach does not envision the direct engagement of poor people in agriculture and food production as a necessary condition for their food security [25]. Food security is instead viewed as an integral dimension of livelihood security, which is shaped by a household's access to a diverse set of endowments, as well as by its capabilities to convert these endowments into entitlements and services [26].

Instead of simply producing or supplying inexpensive food, however, development actors strove to strengthen livelihood security by providing access to natural resources, employment and other entitlements. The support-led security measures shaped by these approaches included government schemes for providing employment, education, health care and skills development. Under the National Rural Employment Guarantee Act (NREGA) in India, an employment scheme was deployed to provide 100 days of work to impoverished rural inhabitants in India, strengthening their entitlements by offering employment opportunities in their villages. These entitlement schemes assisted in the creation of community-level endowments such as local roads, water conservation and the maintenance of drought and flood proofing structures [27].

By contrast, growth-led measures under the entitlement and livelihood approach focused on the deregulation of markets and the development of infrastructure to promote industrial growth, free trade and private investment. These measures created jobs in cities for both low- and high-skilled professionals and encouraged rural out-migration. Many of the rural poor who migrate to cities for employment during the off-season send remittances back to their families in rural areas. Compared to the effects of support-led measures, the impacts of growth-led measures on the eradication of poverty, food insecurity and malnutrition are indirect and highly contentious. A major critique of the entitlement and livelihood approach is the absence of a linear conversion of endowments into food entitlements [28]. Often the rural poor use consumption rationing as an austerity measure against persistent hunger to avoid endowment or asset depletion [29]. In addition, the skewed distribution of power in Indian society often means that powerful forces connected with the state and with market institutions are able to dilute or divert entitlements ostensibly intended for the poor population. Political elites, traders and those controlling the implementation of various entitlement schemes often reap the most benefits, while the poor continue to be deprived of essential resources [30]. Yaro [18] criticizes this approach for treating marginalized people as passive victims rather than active agents of change, thus failing to inspire them to improve their wellbeing. This approach, according to Yaro [18], does not challenge the prevailing structural processes and the value systems of the capitalist state that undermines the endowments, capabilities and local knowledge of poor people.

\section{The food sovereignty approach}

The food sovereignty approach is drawn from a human rights perspective on poverty, hunger and malnutrition. The food activists and development organizations that support small farmers' rights to define their own agricultural and trade policies have played a crucial role in the development of this new rights-based approach to food ${ }^{2}$ [32]. The approach gives farmers a central role in defining their own food and agriculture system, and in protecting and regulating agricultural production and trade in order to achieve self-sufficiency and sustainable development [33]. Food security is attained when small farmers have access to land and sovereign rights to select, cultivate, consume, exchange and trade their own crops [34, 35]. During this process of attaining local food self-sufficiency, the food sovereignty approach recognizes the importance of the economic stability of small-scale farms, local autonomy for decision-making, ecological sustainability and the preservation of nutritional culture through diversity of cultivated food crops [36]. This approach valorizes small-scale farms and downplays the significance of economic growth and market forces that offer opportunities for alternative or non-agrarian livelihoods. Unlike the entitlement approach, the food sovereignty approach grants agency to small farmers and peasants to reorganize existing systems of food

\footnotetext{
2 The idea of 'food sovereignty' was launched at the World Food Summit 1996 by La Via Campesina to protect small farmers against neoliberalism and form a solidarity among small and medium farmers from the global North and South. La Via Campesina is a global peasant movement founded in 1993 by a group of farmers to raise voice against corporate driven agriculture and transnational companies. At present, 164 organizations from 73 countries have joined food sovereignty movement [17, 31].
} 
production controlled by agricultural input providers and the food processing industry.

Although the food sovereignty approach has not adequately addressed constraints faced by small farmers in implementing the ideal conditions of food sovereignty [37], it has reinforced several development ideals, including land reforms, local control over the food market chain, conservation of natural resources and the revival of locally embedded economies. It also extends the provisions of the "right-to-food" recognized in the Universal Declaration of Human Rights (1948) and the International Covenant on Economic, Social and Cultural Rights (1966). Although these legally binding agreements have been almost universally accepted, many nation states have taken a minimal interest in fulfilling some of their provisions, including designing any support-led or growth-led measures for enhancing food security. Several topdown state-sponsored schemes, such as the centralized procurement of food grains for public distribution system (PDS) and the minimum support price for commercial grain crops, force farmers to change their cropping pattern and consumption of food grains, thereby disregarding this rights-based approach [38]. However, a recent shift in public sector institutions at both the national and international levels has occurred. Many of these institutions are now engaging in support-led measures, such as pursuing participatory research with small and marginal farmers to develop technologies for ecological agriculture, as well as providing support for organic certification and labelling. Similarly, growth-led initiatives backed by these institutions include the promotion of fair trade markets and consumer-supported agriculture.

\section{A critical assessment of the three approaches with reference to social wellbeing approach}

The summary presented in Table 1 provides a comparative overview of the three major approaches employed to address the issue of food security. It is important to note that food security is not solely about achieving self-sufficiency in terms of food supply grains, or meeting the caloric requirements of the human body. Rather, food security is associated with the capability of people to exercise foodrelated choices and enhance their social wellbeing. The concept of social wellbeing embraces both objective and subjective aspects of food security $[39,40]$, which relates to the availability of food, access to food and the ability to use and make effective choices for food and livelihood [41]. The objective dimension of food security emphasizes the ends, or physical availability of food and its ability to meet caloric requirements of individuals in a population. The food availability approach was guided by an objective dimension of food security that used production targets, rather than focusing on mode of agricultural practices and the preferences of farmers. Conversely, recognition of the importance of the means of food security underlines the subjective dimension of wellbeing. This dimension emphasizes how food is produced and perceived in nutritional, economic, ecological and cultural contexts. For instance, Agarwal [37] states that male and female farmers within a community view their engagement in small-scale ecological agriculture differently, as their rights over land, access to agricultural technology and credit and power relations within local sociocultural institutions are remarkably different. These socioeconomic distinctions can only be understood, however, if the analysis of food security approaches includes the subjective dimension of wellbeing. The subjective aspects of food security demand an in-depth understanding of

Table 1 Comparative overview of major food security approaches

\begin{tabular}{|c|c|c|c|}
\hline & Food availability & Entitlement and livelihood & Food sovereignty \\
\hline Goal & Increase per capita available food stock & Enhance economic access to food & $\begin{array}{l}\text { Control over production and decision- } \\
\text { making process }\end{array}$ \\
\hline Strategy & $\begin{array}{c}\text { Food production through intensive } \\
\text { agriculture in favourable regions }\end{array}$ & $\begin{array}{l}\text { Access to employment and income } \\
\text { Diversify livelihood portfolio }\end{array}$ & $\begin{array}{l}\text { Right to produce and consume own } \\
\text { choice of food } \\
\text { GMO-free and agro-ecological (includ- } \\
\text { ing organic) agriculture } \\
\text { Safeguard small farms from external } \\
\text { markets and corporate agriculture }\end{array}$ \\
\hline Support-led interventions & $\begin{array}{l}\text { Green revolution with public sector } \\
\text { support } \\
\text { Public distribution system of food }\end{array}$ & $\begin{array}{l}\text { NREGA } \\
\text { Cash transfer }\end{array}$ & $\begin{array}{l}\text { Participatory research } \\
\text { Agro-ecological research } \\
\text { Organic certification and labelling }\end{array}$ \\
\hline Growth-led interventions & $\begin{array}{l}\text { Biotechnology } \\
\text { Agrochemical industry }\end{array}$ & $\begin{array}{l}\text { Free trade and investment } \\
\text { Industrial and infrastructure growth } \\
\text { Rural-urban migration of labour }\end{array}$ & $\begin{array}{l}\text { Farmers' niche markets and fair trade } \\
\text { shops } \\
\text { Consumer-supported agriculture }\end{array}$ \\
\hline Outcome & $\begin{array}{l}\text { Ends oriented: Adequacy for meeting } \\
\text { caloric demand at national level }\end{array}$ & $\begin{array}{l}\text { Capability oriented: Income and fair } \\
\text { wages, skills development, empower- } \\
\text { ment }\end{array}$ & $\begin{array}{l}\text { Means oriented: Self-sufficiency in local } \\
\text { food production without exceeding } \\
\text { carrying capacity of ecosystem }\end{array}$ \\
\hline
\end{tabular}


social norms and institutions, cultural meanings and the ecological and economic realities that underlie food habits [42]. Subjective wellbeing can also be linked to the ecology of practice approach [43], which emphasizes on the importance of indigenous knowledge, sociocultural practices and the experience of local people. The ecology of practice idea rests upon the assumption that the acquisition of basic needs-such as food-are always mediated by social context and power relations.

To summarize the lessons drawn from food security literature, people do not simply strive to attain a particular supply of food, as the food availability approach suggests. Neither do people just seek to build their capability to access food, as the entitlement and livelihood approach believes, or simply seek the freedom to make food-related choices, as the food sovereignty approach suggests. People also persistently look for ways to improve their wellbeing in ways that are meaningful to them. This more nuanced approach to understanding behaviour in sociocultural and agrarian contexts requires approaches such as the ecology of practice. This paper aims to describe the challenges of the existing food security approaches to understanding contemporary rural India, where economic and sociocultural change, ecological degradation, and migration are intensifying. Our findings present an opportunity for researchers, development workers and policymakers to reflect on the limitations of the existing food security approaches, as well as to explore the possibility of applying social wellbeing and the ecology of practice lens as analytical tools to better understand the complex nature of food security in the contemporary changing world.

\section{Research methodology}

\section{The research area}

The research was conducted in Anchetty Panchayat of Krishnagiri district, which is located in the Melagiri Hill Ranges of the Eastern Ghats in the northwest corner of Tamil Nadu, India. The area is one of the poorest in its district, and $36 \%$ of its population lives below the poverty line. It has a literacy rate of $48.3 \%$ [44], which is much lower than the district's literacy rate of $72.4 \%$ or the state level of $80.3 \%$ [45]. The area houses one government hospital, four private clinics, one government secondary school, 23 primary schools and several early childhood education centres. Anchetty is characterized by undulating topography, deep and broad valleys and large tracts of red soil, harbouring predominantly rainfed agriculture. Agriculture is largely subsistence-oriented and is practised by small and marginal farmers ${ }^{3}$. The site

\footnotetext{
${ }^{3}$ In India, households having less than 0.025 acres of land are categorized as landless, $0.025-2.5$ acres as marginal, 2.6-5.0 acres as small, 5.1-10.0 acres as semi-medium, 10.1-25.0 acres as medium and more than 25 acres as large farmers [46].
}

is located close to the two fast growing urban centres of Bengaluru and Hosur. The research site has also experienced numerous support-led and growth-led interventions over the last three decades that have enhanced food production and access to food and employment. Some of the major interventions in this area have included PDS for food, subsidized agricultural inputs, watershed development schemes, information about various agricultural schemes, and the NREGA employment scheme.

Anchetty was also a project site for a large interdisciplinary research project entitled "Revalorizing small millets: Enhancing the food and nutritional security of women and children in rainfed regions of South Asia using underutilized species" (RESMISA), launched in 2011 by a local NGO, DHAN Foundation, together with partners from academic and research institutions in South Asia and Canada. The RESMISA project was intended to promote cultivation, production, value addition and the consumption of nutritious small millets to strengthen nutrition security in the region. Although the project utilized several elements of the classical food availability/ production approach, it also emphasized participatory technology development, gender analysis, culturally preferred nutritious food and farmers' indigenous knowledge. Many of these attributes are integral to the food sovereignty approach. The research conducted for the present study was not intended to evaluate the impacts of the RESMISA project.

The field research was conducted in the four villages of Anchetty Panchayat, namely, Thamsanapalli, Pudhur, Bailkadu and Ermuthunapalli. Anchetty Panchayat includes 19 small villages or hamlets located around the central hub, known as the main Anchetty village, with a rural market, transportation depot and some block-level government offices. All four study villages are located within a 2-6 km radius of Anchetty village. These villages (referred to collectively as Anchetty) were selected in consultation with the RESMISA field staff and key informants, based on the prevalence of growth-led and support-led interventions, as well as on the diversity of their livelihood portfolios, including rural-urban migration, small-scale agriculture and local off-farm activities.

\section{Research design, data collection and analysis}

The research was designed after an in-depth review of the conceptual and analytical frameworks discussed earlier in this paper. Embracing an inductive and interdisciplinary research design, this study combined both quantitative and qualitative data collection methods. Before conducting fieldwork, the project received ethics approval from the Research Ethics Board of Research Ethics and Compliance Office at the University of Manitoba and the Canadian Mennonite University Ethics 
Review Committee. The approvals were according to TriCouncil Policy Statement (2): Ethical Conduct for Research Involving Humans (TCPS) of the Government of Canada. ${ }^{4}$ Identified as a minimal risk project, it assured voluntary participation, prior informed consent, and safeguarding privacy and confidentiality of the research participants in the field. The ethics statements were prepared with the contact details of the Principal Investigators and were read in front of the research participants before starting the data collection through the household survey, group discussions and qualitative interviews. A small number of participants chose to provide their written consent, while others provided a verbal consent. A copy of the prior informant consent statement was also provided to each of the research participants for their records.

Quantitative data were collected using a semi-structured survey in 68 households with a population of 390 individuals, while qualitative methods included participant observation, focus group discussions and key informant and in-depth interviews. The fieldwork was conducted in 2012 and 2014, and was supported by a local research assistant on both occasions. The research assistant assisted in organizing the focus groups and individual interviews, as well as in translating sessions and answering questions during participant observation. A household list made available by the RESMISA project office in Anchetty was updated with the help of key informants. The updated list of 459 households was used as a sampling frame, and one-sixth of the households were selected for interviews, creating a sample of 76 households, using systematic random sampling. Eight households, however, could not be found during home visit attempts or did not respond, leaving a sample total of 68 households. The survey sought to discover the socioeconomic and demographic profiles of the research participants, including information about landholding, agriculture, food selfsufficiency and objective and subjective measurements of wellbeing. The qualitative methods focused on personal observations and experiences of the research participants and the researcher during the data collection.

The wellbeing of the participants was estimated by an index that measured several variables related to the level of access to resources (access to income, housing and drinking water), as well as the adequacy of resources (adequacy of income, housing, drinking water, child education, healthcare facilities, and emotional and social

\footnotetext{
4 The TCPS describes the policies of the Social Sciences and Humanities Research Council of Canada (SSHRC), the Canadian Institutes of Health Research (CIHR), and the Natural Sciences and Engineering Research Council of Canada (NSCERC), which expresses these three government agencies' continuous commitment to promote the ethical conduct of researches that involve human subjects.
}

relationships). Emotional relationships referred to intrahousehold relationships among members, while social relationships were defined as the relationships of households with other community members. This index also included a subjective evaluation of the participants' quality of life over the past 12 months, based on overall life satisfaction and their perception of their quality of life in relation to other members in the community. These 12 variables were measured on a three-point scale with the following grading: (1) low; (2) medium; and (3) highly accessible, adequate or satisfied, as experienced by the respondent. The individual responses for these variables were combined to create the participants' overall wellbeing index, with scores ranging from 12 to 36 .

The qualitative data were analysed through qualitative content analysis, while the quantitative data utilized Excel and IBM Statistics 19 to complete descriptive statistics, correlation and ANOVA. The researchers benefitted from another independent baseline study [44] conducted by the RESMISA project in the same area, which involved surveying 200 households on the availability and consumption of food; nutrition and health statuses using anthropometric measures; landholding, agriculture production and constraints; and changes in agrobiodiversity, local market chains and livelihood patterns. The understanding gained from this baseline study [44] helped in interpreting some of the quantitative trends and qualitative insights reported in this paper.

\section{Results}

\section{Profile of the respondent households}

The majority of respondents were middle-aged (ranged $19-88$ years, average 39.6 years), female $(71 \%)$ and married (91\%). All of the households were Hindu, with $72 \%$ belonging to the Most Backward Caste (MBC) group. ${ }^{5}$ The literacy rate was very low $(57 \%)$ in comparison to the district $(72 \%)$ and state $(80 \%)$ levels. Among the literate respondents, the average duration of schooling was 6.4 years (Table 2). The average monthly income was INR 3717 (US\$69). The majority of respondents (69\%) lived in houses made of clay-bricks or stone blocks with tile roofing, while $28 \%$ had concrete houses and the remaining $3 \%$ had clay-bamboo walls and thatched roofs. Almost all households $(98 \%)$ had access to public water taps for drinking, while three per cent also had bore-wells in their yards.

Over two-thirds (69 \%) of households reported agriculture as their primary occupation; however, many

\footnotetext{
5 The Most Backward Caste (MBC) is a collective term used by the state Government of Tamil Nadu to classify caste groups that are socially and educationally disadvantaged. It is a category in addition to Scheduled Caste (SC), Scheduled Tribe (ST) and Other Backward Caste (OBC) groups that are categorized by the central government as eligible for state-sponsored schemes.
} 
Table 2 Socioeconomic and demographic profiles of the respondent households

\begin{tabular}{|c|c|c|}
\hline Particulars & No. & $\%$ \\
\hline \multicolumn{3}{|c|}{ Household size (mean 5.7; min. 2; max. 14) } \\
\hline$\leq 4$ members & 28 & 41.2 \\
\hline $5-6$ members & 22 & 32.4 \\
\hline$\geq 7$ members & 18 & 26.4 \\
\hline \multicolumn{3}{|c|}{ Age of respondent (mean 39.6; min. 19; max. 88) } \\
\hline$\leq 30$ years & 23 & 33.8 \\
\hline $31-60$ years & 38 & 55.9 \\
\hline$>60$ years & 7 & 10.3 \\
\hline \multicolumn{3}{|l|}{ Marital status of respondent } \\
\hline Married & 62 & 91.2 \\
\hline Unmarried & 3 & 4.4 \\
\hline Widow/widower & 3 & 4.4 \\
\hline \multicolumn{3}{|c|}{ Years of schooling (mean 6.4; min. 0; max. 10) } \\
\hline 0 years & 43 & 63.2 \\
\hline$\leq 5$ years & 14 & 20.6 \\
\hline$\geq 6$ years & 11 & 16.2 \\
\hline \multicolumn{3}{|c|}{ Caste/ethnic characteristics of households } \\
\hline Scheduled caste (SC) & 5 & 7.4 \\
\hline Scheduled tribe (ST) & 3 & 4.4 \\
\hline Other backward caste (OBC) & 7 & 10.3 \\
\hline General caste (GC) & 4 & 5.9 \\
\hline Most backward caste (MBC) & 49 & 72.0 \\
\hline
\end{tabular}

respondents had more than one occupation as a result of opportunities offered by growth-led interventions located within and outside of their village. Based on their engagement in agriculture and other non-farm livelihood sources, the households were classified into four occupational categories: (1) households whose sole primary profession was agriculture (HHAP); (2) households based on agriculture and off-farm activities within the village or local area (HHAL); (3) households based on agriculture and off-farm activities in distant places (HHAD); and (4) households where agriculture was not a means of living (HHNA). These categories were the basis for analysis of primary data collected on food security, livelihood and wellbeing.

\section{Food sufficiency and nutrition security: the role of small-scale agriculture}

While $13.2 \%$ of the respondents were small farmers with more than 2.5 acres of land, the rest of the farmers were either marginal farmers or landless labourers. Table 3 shows the solely agricultural-based households (HHAP) having the highest average landholding size (2.1 acres), followed by the households based on agriculture and off-farm activities within the village (HHAL) and the households based on agriculture and off-farm activities outside the village (HHAD) categories. A quarter of the respondents belonged to the landless category (HHNA); these households earned their livelihood through wage labour within and outside of the village. Data suggested that more than $50 \%$ of the HHADs rented their land to other farmers. Many of the farmers renting out their land were engaged in off-farm employment in nearby cities such as Hosur and Bengaluru. Although the scale of leasing land appeared to be small (11.8\%), qualitative observations indicated that there was a widespread phenomenon of renting or sharecropping in the area. Participants in group discussions unanimously reiterated that the trend of renting out land is burgeoning in their villages, as people seek employment in distant labour markets. Despite the widespread practice of leasing farmland, however, participants were apparently hesitant to reveal information on renting or sharecropping in any formal survey at the household level. Land is a sensitive issue in India, as property rights are recognized on the basis of the real cultivator of the land. As the legal system does not encourage rent-seeking by absentee landowners, it is understandable that people would hesitate to share information at an individual level. Furthermore, this sharecropping or renting is commonly arranged within one's extended family or through kinship networks, posing further challenges in precisely measuring the scale of renting land. Farmers expressed their concern over the fertility

Table 3 Landholding, livestock and crop diversity among the household types

\begin{tabular}{lllll}
\hline Household type & N & $\begin{array}{l}\text { Total land } \\
\text { cultivated (acres) }\end{array}$ & $\begin{array}{l}\text { Livestock } \\
\text { population }\end{array}$ & $\begin{array}{l}\text { Crop diversity } \\
\text { HHAP (households based on agriculture) }\end{array}$ \\
$\begin{array}{l}\text { HHAL (households based on agriculture and } \\
\text { off-farm activities in local areas) }\end{array}$ & 26 & 2.1 & $3.4^{\mathrm{a}}$ & 3.3 \\
$\begin{array}{l}\text { HHAD (households based on agriculture and } \\
\text { Off-farm activities in distant places) }\end{array}$ & 10 & 1.5 & $2.3^{\mathrm{a}}$ & 2.8 \\
$\begin{array}{l}\text { HHNA (households based on non-agricultural activities } \\
\text { within and outside the village) }\end{array}$ & 17 & 1.3 & $1.5^{\mathrm{a}}$ & 0 \\
\hline
\end{tabular}

\footnotetext{
a Statistical means are significantly different at 0.05 level (one-way ANOVA)
} 
and productivity of land in the face of prevailing land management practices of either leasing or sharecropping.

The trends presented in Fig. 1 illustrate food sufficiency among respondent households, which is the ability of a household to meet its food requirements from its own farm. People in the HHNA category, whose livelihood is derived from non-farming activities, were excluded from this analysis, as they could not meet the definition of food sufficiency stated above. Results indicated that only a quarter of the households produced enough food from their land in the preceding year for a full 12 months. Those in the HHAP and HHAL categories, which have a stronger agricultural base, were more food self-sufficient compared to the HHADs. It is important to note, however, that almost one-fifth of the HHAPs (19\%) were unable to meet their food requirements for more than 6 months, as most of these farmers found their landholdings to be too small.

Although the majority of respondents were unable to produce an adequate food supply from their own land, they also obtained food from other sources. The vast majority of the households (96\%) reported that they had not skipped a single meal in the past 12 months due to insufficient food supply from their own production. All of the households reported a dependence on PDS entitlements for food. As the overwhelming majority of respondents (91.2\%) hold BPL (below poverty line) cards, they were entitled to food grains supplied through PDS. The Tamil Nadu government provides $20-35 \mathrm{~kg}$ of rice grain per month per household (of four members) at no charge, as well as wheat, pulses, palm oil, sugar and kerosene at a minimal cost [47]. Another important source of household food supply for the participants was the wage income they made within and outside the village, including NREGA employment and out-migration.

Even though the availability and accessibility of and the entitlement to food did not appear to be a problem, the quality of the food supply is also important to consider. Quality depends on the type of agricultural practices in the area, as well as on the availability of quality food in the market or supplied through PDS. Several studies have indicated that the provision of processed rice through PDS in Tamil Nadu reduced dietary diversity and caused malnutrition $[48,49]$. Those who promote the food sovereignty approach cite the importance of smallscale agriculture and homestead gardens for providing diverse and nutritious food in line with cultural preferences [22]. Apart from the major green revolution crops such as rice, wheat and corn, Anchetty farmers cultivated several nutritious crops such as millets, sorghum, vegetables, groundnut and various pulses (red gram, field bean, horse gram and chickpea). These crops are not only a primary source of important vitamins, calcium and protein, but they also enhance dietary diversity. Table 3 demonstrates the higher crop diversity on HHAP farms as compared to the HHALs and HHADs. The cultivation of pulses and finger millet was less popular among the HHAL and HHAD categories, as crop diversity demands more land, labour and other resources. Over $70 \%$ of the HHAP respondents, however, had grown finger millet and various pulses within the last 12 months. A recent study has indicated that farm production diversity (including crop and livestock diversity) is positively correlated with household dietary diversity [50]. This implies

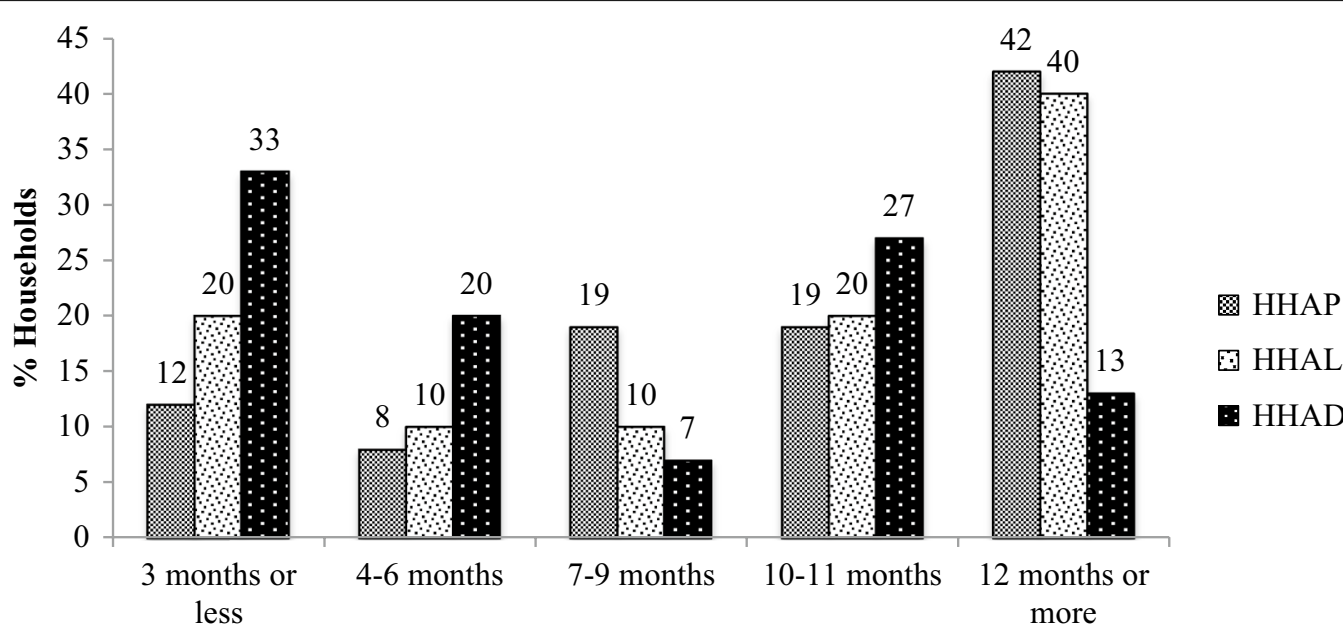

Food self-sufficiency in months

Fig. 1 Food self-sufficiency among the household categories. HHAP households based on agriculture, HHAL households based on agriculture and off-farm activities in local areas, HHAD households based on agriculture and off-farm activities in distant places 
that HHAP households may have better access to diverse and nutritious food compared to other household types.

In addition to crop diversity, the integration of livestock is another salient feature of peasant or small-scale agriculture. Crop-livestock integration plays an important role in both the ecological sustainability of small-scale agriculture and in addressing the supply deficit of protein and other vitamins that contribute to malnutrition [35]. The respondents were found to have large (cattle, buffalo) and small (goat, sheep) ruminants, and poultry raised in their homestead for draught purposes, farm yard manure, and milk and meat supply for home consumption and to get additional household income from sale. Statistics presented in Table 3 indicate that HHAPs had a significantly higher number of animals (cattle, buffalo, goat and sheep) compared to other households. Interestingly, however, HHNAs were engaged in keeping livestock even though they did not have agricultural land. Considering the importance of livestock in meeting the economic and nutritional needs of a household, these landless households raised their animals with feed and fodder accessed primarily from common property resources or as in-kind agricultural wages received from other farmers. As these livestock are difficult to maintain, participants expressed their concerns over the declining population of livestock in the region. One key informant said, "Many migrant families do not want to own more cattle. If people want to go out for work, they have to sell them off. Thus, the number of cattle is decreasing year by year" (ANIV_0112, 2012.09.30). Participants stated that the reasons for selling their livestock were to acquire cash to cover costs for migration, as well as to avoid having to find arrangements for livestock care while they were away. The combined decline in crop diversity and livestock population had an impact on the quality of food supplied through household production, while the food supplied through the PDS and the market was found to be of inferior quality [51].

\section{Wellbeing: The role of agricultural and off-farm livelihood portfolios}

As well as considering a household's ability to meet food and nutrition requirements, it is crucial to examine how agricultural and non-agricultural livelihoods have an impact on the overall wellbeing of the household. As explained in the methodology section of this paper, a wellbeing index was calculated using observations recorded on the access to and adequacy of various resources, as well as a subjective evaluation of the household's quality of life in the past 12 months. The statistics presented in Table 4 demonstrate that agricultural households with additional off-farm employment, either from local or distant sources (HHAL and HHAD), scored higher on the wellbeing index, though the HHAL statistical mean is not significantly different from the others. The HHAP respondents had a considerably lower placement on this index, as their wellbeing was constrained by an unstable monthly income due to inadequate land, declining agricultural productivity and diminished life satisfaction. Although the landless households (HHNA) had a slightly higher income, their placement on the wellbeing index was reasonably at par with the farming households (HHAP). Most of the HHNA respondents earned a livelihood from wage labour, with low average daily wage rates of about INR 200 (US\$3.70) for men, and INR 100 (US\$1.85) for women. They were, however, able to meet their food requirements from PDS entitlements and market sources.

Table 5 presents a correlation matrix of the wellbeing index and important variables that contribute to household food security. The wellbeing index is positively correlated with food self-sufficiency and landholding; however, this correlation is weaker than the correlation to monthly income. Livestock population and crop diversity-both of which are important contributing variables to food and nutrition sufficiency-failed to show strong correlations to the wellbeing index. As the maintenance of crop diversity and livestock demands intensive labour from households, households do not see these as positively contributing to their wellbeing.

The quantitative results show that the households engaged in off-farm activities have a higher household income and level of wellbeing; the qualitative data indicate a different scenario. Many households had at least one member engaged in seeking non-farm employment offered

Table 4 Household size, monthly income and wellbeing index

\begin{tabular}{llll}
\hline Household type & Nousehold size & Wellbeing index & Monthly income (INR) \\
\hline HHAP (households based on agriculture) & 265.5 & $21.5^{\mathrm{a}}$ & $2894^{\mathrm{a}}$ \\
HHAL (households based on agriculture and off-farm activities in local areas) & 105.3 & 23.0 & $5325^{\mathrm{ab}}$ \\
HHAD (households based on agriculture and off-farm activities in distant places) & 157.2 & $23.3^{\mathrm{ab}}$ & $4717^{\mathrm{ac}}$ \\
$\begin{array}{l}\text { HHNA (households based on non-agricultural activities within and outside the vil- } \\
\text { lage) }\end{array}$ & 175.0 & $21.2^{\mathrm{b}}$ & $3147^{\mathrm{bc}}$ \\
\hline
\end{tabular}

$a, b, c$ Statistical means with the same letter in the same column are significantly different at 0.05 level in the case of monthly income and at 0.1 level in the case of the wellbeing index (one-way ANOVA) 
Table 5 Correlation matrix of wellbeing index and key variables of food security at household level $(N=68)$

\begin{tabular}{|c|c|c|c|c|c|c|}
\hline Variables & 1 & 2 & 3 & 4 & 5 & 6 \\
\hline 1. Food self-sufficiency & 1 & & & & & \\
\hline 2. Landholding & $0.325^{*}$ & 1 & & & & \\
\hline 3. Crop diversity & $0.495^{* *}$ & 0.075 & 1 & & & \\
\hline 4. Livestock population & $0.357^{* *}$ & $0.281^{*}$ & $0.380^{* *}$ & 1 & & \\
\hline 5. Monthly income & 0.182 & 0.144 & 0.079 & 0.106 & 1 & \\
\hline 6. Wellbeing index & $0.308^{*}$ & $0.325^{*}$ & 0.057 & -0.067 & $0.541^{* *}$ & 1 \\
\hline
\end{tabular}

* Correlation is significant at 0.05 level

** Correlation is significant at 0.01 level

by growth-led interventions in the area. About $31 \%$ of the households surveyed had migrant members working in urban areas either within or outside the geographical boundaries of the state. Data indicate that most of the households had been engaged in off-farm employment for the last 10 years at minimum. Although there was no record stating when out-migration started in the area, it is evident that this trend is increasing every year. One of the respondents stated, "Migration in this village started long ago, but the tendency has increased in the last 25 years" (ANIK_0312, 55, 2012.09.30). Of the 30 migrants, most of them were young (average 30 years), male $(83 \%)$, married (73\%), a child of the household head (77\%) and working in the unskilled sector as factory workers, wage labourers, cleaners and so forth (63\%). Depending on the travel distance, migrants returned home as little as once a year to a maximum of once a month, with average home visits of 4.4 times a year. The participants viewed out-migration as not always the most preferred livelihood option, but inevitable at times. Comparison was frequent between small-scale agriculture and off-farm migration in the focus group discussions or individual conversation.

It (labour migration) has been affecting agriculture, but there is no other way than going out to work. There is no life here without migration. If you depend on agriculture you wait for many months, yet there is no guaranteed income, the crop may fail due to drought, wild boars may damage it; but if you work as labour, you will get something at the end of the day (ANFG_0112, 2012.10.04).

A participant in another focus group explained:

Because of lower yield from agriculture, it is hard to manage households. The extended drought hits us every year. The income that can be made from wage labour is more than the income from agriculture (ANFG_0212, 2012.10.05).

Regarding caste and ethnicity, the sample distribution was highly skewed towards the MBC group (72\%), due to a lower prevalence of higher and general caste households in the study villages. In light of the skewed distribution of sample households, one cannot draw meaningful inferences from the quantitative analysis. As the MBC group is considered the lowest in the caste-based hierarchy, these individuals qualified for all of the welfare and entitlement schemes providing food, livelihood, education and other services. Interestingly, MBC households in Anchetty had considerable access to land (1.83 acres) and off-farm employment, and consequently, earned the highest monthly income of all the caste groups (INR 3973 or US\$73.50). Despite their reasonable access to land, food sufficiency and monthly income, the average wellbeing index of $\mathrm{MBC}$ households was relatively lower than that of other caste groups. This is perhaps due to their lower social status, which cannot be easily changed by a higher monthly income in caste-based rural Indian society. Studies have shown that while a higher household income is helpful in increasing wellbeing up to a certain point, it becomes less significant in terms of increasing long-term life satisfaction [40, 52]. Simply put, money does not always play a significant role in contributing to greater wellbeing; other social, cultural and interpersonal factors do also matter.

\section{Wellbeing and gender: the role of NREGA entitlements and other off-farm livelihood options}

Apart from seeking employment in distant places, households in the Anchetty area had employment opportunities in various village level projects under NREGA. As discussed in the literature section of this paper, NREGA is an employment entitlement scheme that seeks to reduce the seasonal out-migration of the rural poor and bring gender parity in rural wages [53]. Despite the NREGA scheme, however, the gender disparity in daily wages continues in the open labour market in the region. According to the focus group participants, men receive INR 200-300 per day (US\$3.70 to \$5.50) in the open labour market, and thus did not find the NREGA work with low wages (INR 100/day, or US\$62.66) attractive. 
Conversely, the NREGA work is a viable alternative for rural women, as the supply and wages of jobs during the off-season for women are lower in the open market. The results indicate that all of the workers employed in NREGA schemes in the studied villages were women. Due to this phenomenon, NREGA has become a de facto employment scheme for women. Kelkar [54] found a similar trend, as $82 \%$ of the workers in NREGA schemes across Tamil Nadu were women.

Table 6 indicates that the engagement of women in NREGA jobs significantly increased their monthly income and the wellbeing of both agricultural and offfarm households. The impact of the NREGA entitlements on the wellbeing of agricultural households was even higher than for respondents who took market-led off-farm employment opportunities from local and distant places. However, households that primarily relied on jobs provided through NREGA work had the lowest monthly incomes and the lowest rank on the wellbeing index. Thus, NREGA entitlement is only beneficial if the households have agriculture as their primary livelihood. The households that were either landless or had too small an amount of land for agriculture to be viable did not prefer NREGA entitlements. Most of them opted for distant off-farm employment with more remuneration and, those that did so, marginally had the highest ranking on the wellbeing index.

Although the majority of respondents were women, the study did not compare the wellbeing of men and women within a household. Qualitative aspects of this inquiry focusing on the experiences of women, however, revealed that NREGA did not necessarily improve a woman's wellbeing even if it was de facto labelled as a women's employment scheme. Rather, these women felt overburdened due to their household responsibilities, agricultural work and NREGA employment. Women's responses throughout this project are a clear indication of how

Table 6 Effects of NREGA on agricultural and non-agricultural households

\begin{tabular}{llll}
\hline Household type & $\boldsymbol{N}$ & Monthly income (INR) & Wellbeing index \\
\hline Agriculture & & & \\
No off-farm & 26 & $2936^{\mathrm{a}}$ & $21.7^{\mathrm{a}}$ \\
NREGA & 16 & $4979^{\mathrm{a}, \mathrm{b}}$ & $23.3^{\mathrm{a}, \mathrm{b}}$ \\
Non-NREGA off-farm & 9 & $4167^{\mathrm{a}, \mathrm{c}}$ & $22.3^{\mathrm{c}}$ \\
Non-agriculture & & & \\
NREGA & 7 & $2393^{\mathrm{b}, \mathrm{c}, \mathrm{d}}$ & $18.0^{\mathrm{a}, \mathrm{b}, \mathrm{c}, \mathrm{d}}$ \\
Non-NREGA off-farm & 10 & $4250^{\mathrm{a}, \mathrm{c}, \mathrm{d}}$ & $23.4^{\mathrm{d}}$ \\
\hline
\end{tabular}

$\overline{a, b, c, d}$ Statistical means with the same letter in the same column are significantly different at 0.05 level (one-way ANOVA) rural labour is increasingly feminized, largely due to male out-migration. One of the respondents stated,

It is difficult to manage a household alone, but I have been doing it for a long time for the betterment of the children and us. The children are grown up now, but I have to take care of the cattle, the farm, and everything. On top of that I have to go for NREGA work almost every day. When he [the husband] is here I feel relieved. Even though he does not help in any household tasks, he helps in agricultural work like harvesting groundnuts, ploughing etc. (ANIP_0212, 35, 2012.10.09).

This increased responsibility and heavier workload for women, seen as a result of development initiatives, is not a new phenomenon. Agarwal [55] observed several successful joint forest management projects in South Asia that doubled the workload of female participants. In Anchetty, the responsibilities of women in many households increased threefold in the absence of their male partners. This trend of feminization in rural areas is an emerging phenomenon witnessed across South Asia today $[56,57]$.

Rural feminization has greatly increased the demand for male labour to complete specific agricultural tasks. An analysis of recent data concerning rural wages (1995-2012) in Tamil Nadu showed higher growth rates for typical "male" tasks such as ploughing, masonry, carpentry and driving compared to the tasks predominantly completed by women [58]. These growth rates make it difficult for state-led entitlement schemessuch as NREGA-to be viable as an alternative source of employment for men. The English daily, The Hindu [59], reported that NREGA wages are even lower than wages offered to prisoners in India. Unless the NREGA rates increase to a viable level, which would help create an effective balance of male-female labour distribution within households, the wellbeing of women in India will continue to deteriorate, despite increases in household income and the availability of food in local markets.

\section{Discussion and conclusion}

Food security is measured through a household's access to food, supplied through its own production or through entitlements or market sources. The results presented in the previous section of this paper illustrate how small and marginal farmers in resource-poor areas experience development initiatives in rural areas while seeking to fulfil their everyday livelihood needs, including food and nutrition, and improving their wellbeing. Three components assisted in meeting the food and nutrition needs of participants in the community: (1) landholding and its management; (2) the integration of crop diversity and 
livestock with small-scale agriculture; and (3) the access of household members to PDS and multiple employment opportunities in the region and distant markets. This study also demonstrated that food security measures do not always have a positive linear relationship with the wellbeing of a household. The interaction of food security and wellbeing, rather, is shaped by economic, environmental and sociocultural complexities, what Nyerges [43] describes as the ecology of practice, which are prevalent in rural areas. Anchetty farmers have become active participants in strategizing and navigating the challenges and opportunities offered by the changing agrarian landscape in their region.

Households with a livelihood portfolio primarily based on agriculture (HHAP) are ideal candidates for fostering the vision of small-scale agriculture put forward by the food sovereignty approach. These households' capacities to attain food sufficiency could be strengthened if the small farmers gained greater control over their land, production, labour and market forces. As the findings of this study illustrate, however, these farmers face enormous challenges in ensuring nutritional, economic and ecological security, due to the small size of their farms. The anthropometric measures analysed by Karthikeyan et al. [44] reveal that significant proportion of children under the age of six in the Anchetty villages were found to be underweight based on their body mass index (BMI). ${ }^{6}$ These widespread malnutrition trends ${ }^{7}$ observed among the children could not be explained by historical differences based on landholdings or caste that existed at the research site. Similarly, no significant differences were found in the high level (36.4 \% of women surveyed) of chronic energy deficiency (CED) reported among adult women (15-49 years) between those from landless households and those from households with less than five acres of agricultural land [44]. This indicates that small farms in the HHAP category, with the existing level of crop diversity and livestock population, were not able to meet the adequate nutritional requirements of children and women in their families. This finding calls into question idealized notions about the self-sufficiency and independence of small-scale farms (below five acres in India) being sufficient to meet the diverse nutritional needs of a family. The inability of the universal public food distribution system to

\footnotetext{
${ }^{6}$ Body mass index (BMI) is the relative weight of an individual with respect to their mass and height, measured as $\mathrm{kg} / \mathrm{m}^{2}$ in metric units. It is used to calculate the chronic energy deficiency (CED), which occurs when a person is underweight for their respective age. For the reproductive age (1549 years), a BMI of lower than 18.5 is considered to be chronically energy deficient [60].

${ }^{7}$ A systematic scientific investigation, using a large sample of the population $(n=753)$ and trained health professionals as surveyors, conducted by Little et al. 2015 in Anchetty villages reported $24.8 \%$ of male and $20.9 \%$ of female adults (20 years or older) as underweight based on their BMIs [61].
}

bridge this nutritional gap is clearly evidenced by the poor public health indicators in the region. For this reason, Bernstein [62] shows scepticism about the claim of the food sovereignty approach that small-scale agriculture can feed the world, as it overlooks crucial elements of agrarian political economy.

Mainstream agricultural research institutions, founded on the premise of the food availability approach, are biased towards green revolution crops such as rice, wheat, maize, cotton and oilseed. Top-down agricultural research narrowly focused on these mainstream crops has failed to make any positive impacts on Anchetty farmers facing low productivity, the degradation of soil and declining agrobiodiversity. Due to the economic and ecological challenges currently confronting smallscale agriculture in India, farmers view agriculture as a low-status profession and consider access to diverse sources of income as necessary for fulfilling their wellbeing aspirations. With limited capacity to stabilize their own livelihoods, farmers find it difficult to exercise their rights and autonomy to influence decision-making in and control over the local food market. In addition, in today's globalizing world, livelihood requirements extend beyond two meals a day. Households want to progress and improve their wellbeing with the best possible means they can pursue. For instance, every household included in the study expressed a desire to have a toilet installed in their residence. At the time, the only household that had fulfilled this desire was an HHAD household. Farming households expressed concerns regarding the instability and stagnation of their agricultural income, which constrains their ability to ensure the educational, nutritional and other needs of their children. Of the households studied, $25 \%$ of the children were enrolled in distant private schools; these children were predominantly from the households (HHAL and HHAD) that had income from off-farm employment.

Hasan et al. [63] found that approximately half of India's agricultural labour force-which has the lowest average labour productivity among all sectors, at $29 \%$-is trapped in a vicious cycle of low productivity and poverty. The quest for better wellbeing, including attainment of a 'modern' lifestyle, compels small and marginal farmers to seek off-farm employment, including labour outmigration, in local or distant market economies [64-66]. Although rural out-migration is not a new phenomenon in India, it has previously been primarily limited to arid and tribal areas where state and market forces were historically weak. However, recent trends of out-migration have been observed nation-wide, including in intensive agricultural areas that host a stronger presence of stateled and market-led forces of growth [67]. In a nationwide survey carried out by the Government of India, $40 \%$ 
of 51,770 farm households (from 6,638 villages across India) said they did not like farming, and given the choice would choose a different livelihood source [37, 68]. Furthermore, $76 \%$ of these farmers who did not enjoy farming owned less than 2.4 acres of land, an amount similar to the amount owned by the majority of farmers in the Anchetty villages. Although the declining role of agriculture in providing livelihoods and employment is an unprecedented, and perhaps irreversible, phenomenon for the Indian subcontinent, it is predictable given the focus of neoliberal policies on a growth-led economy featuring industrial and urban development.

Food entitlements provided through PDS and other schemes or employment entitlements provided by NREGA were found to be insufficient to prevent or reverse out-migration of people from the agrarian sector. Despite the ineffectiveness of these entitlements, however, Anchetty farmers were not overly pessimistic about their present situation. Instead, the farmers are striving to become active participants in the process of change, strategizing and navigating the challenges and opportunities offered by the changing contexts of agrarian development. These farmers seek to creatively maximize the resources and opportunities available to them in their everyday livelihood practices [69]. Bernstein [70] rightly argues that in the contemporary agrarian economy, the capital required to pursue rural livelihoods is not only generated from within the rural areas, but also expanded and diversified by using non-agrarian sources outside the countryside. While unpacking the process of agrarian development in the study community, our findings underscore how income received from a diversified livelihood portfolio enhances access to food provisions and the objective wellbeing of the household, but it does not necessarily improve their subjective wellbeing. The impacts of alternative livelihoods offered by NREGA entitlement or distant markets need to be examined in the context of the wellbeing of women within a household. The particular perspectives of women on subjective wellbeing reiterate the importance of examining the distribution of resources and decision-making processes within the household or farm level, as compared to community and national levels.

To summarize, the existing food security approaches do not take into account people's subjective experiences of everyday livelihood practices, and their aspirations for, and struggle to achieve, better wellbeing, particularly in ecologically fragile areas such as Anchetty. Ecological and economic conditions are simply too precarious in that area for food sovereignty or food availability approaches to ensure food security. Increases in entitlements through state-based schemes have allowed for some local diversification of livelihoods, but are insufficient to counter the aspiration-driven pull of out-migration. By paying more attention to the subjective aspect of wellbeing, the role of individual agency in seeking livelihood improvement, and the structural forces connected to agrarian development, the effectiveness of existing food security approaches can be enhanced.

\section{Abbreviations}

ANOVA: Analysis of Variance; BMI: Biomass Index; BPL: Below Poverty Line; CIFSRF: Canadian International Food Security Research Fund; CIHR: Canadian Institutes of Health Research; DFATD: Department of Foreign Affairs, Trade and Development; DHAN: Development of Human Action; GDP: Gross Domestic Product; IDRC: International Development Research Centre; INR: Indian Rupees; MBC: Most Backward Caste; NREGA: National Rural Employment Guarantee Act; NSCERC: Natural Sciences and Engineering Research Council of Canada; PDS: Public Distribution System; RESMISA: Revalorizing Small Millets: Enhancing the Food and Nutritional Security of Women and Children in Rainfed Regions of South Asia Using Underutilized Species; SSHRC: Social Sciences and Humanities Research Council of Canada; TCPS: Tri-Council Policy Statement; US\$: United States Dollar.

\section{Authors' contributions}

KP took the lead in terms of the theorization of food security and its relation to the paper's main argument. HG provided the lead role in all stages of conducting research and preparing publication. KP and DJ were involved in conceptualization of the specific research within the broader context of the RESMISA project, and made significant contributions to survey instruments, research methodology, data analysis and interpretation, and preparation of the manuscript. MK provided support for identifying a relevant research problem for the local community, data collection in the field, and interpretation of data. All authors read and approved the final manuscript.

\section{Authors' information}

Dr. Kirit Patel is an Assistant Professor, International Development Studies Program, Menno Simons College affiliated with the University of Winnipeg and Canadian Mennonite University, Winnipeg. Dr. Patel has extensive experience as an academic, development policy analyst, and community development practitioner. He is the principal investigator of an interdisciplinary research project, funded under the Canadian International Food Security Research Fund from the IDRC, examining production, distribution, value addition and consumption of small millets in India, Nepal and Sri Lanka.

Dr. Hom Gartaula is a Postdoctoral Researcher at the International Development Studies program of Canadian Mennonite University in Winnipeg, Manitoba, Canada. He completed his PhD in Social Sciences with interdisciplinary focus on the Sociology and Anthropology of Development from Wageningen University in the Netherlands. Dr. Gartaula is an experienced researcher, educator and practitioner in the field of international development with particular interest in agrarian change, food security, labour migration, gender, and social wellbeing.

Dr. Derek Johnson is an Associate Professor of socio-cultural anthropology at the University of Manitoba. He works in the areas of international development and natural resource governance with a primary focus on small-scale fisheries. His main geographical area of interest since the mid-1990s has been South Asia, and particularly the Indian state of Gujarat.

Mr. M. Karthikeyan is working as a Program Leader with Rainfed Farming Development Program of DHAN Foundation, a leading pan Indian NGO in India. He was the Indian lead PI for the IDRC and DFATD funded CIFSRF project, 'Revalorizing Small Millets in Rainfed Regions of South Asia'. For the past eleven years he has been instrumental in organizing rainfed farmers and designing and implementing various rainfed-farming interventions in various parts of India, including the Mutual Crop Insurance.

\section{Author details}

${ }^{1}$ International Development Studies, Menno Simons College, Canadian Mennonite University, 520 Portage Avenue, Winnipeg, MB R3C 0G2, Canada. ${ }^{2}$ Department of Anthropology, University of Manitoba, Winnipeg, MB, Canada. ${ }^{3}$ DHAN Foundation, Krishnagiri, Tamil Nadu, India. 


\section{Acknowledgements}

The Social Sciences and Humanities Research Council of Canada (SSHRC) financially supported this research under its Postdoctoral Fellowships programme. The research also received support from the Canadian International Food Security Research Fund (CIFSRF), a programme of Canada's Internationa Development Research Centre (IDRC), undertaken with the financial support of the Government of Canada provided through Foreign Affairs, Trade and Development (DFATD), Canada. The authors are indebted to Sally Humphries from the University of Guelph for her substantial contribution on research design and shaping arguments in the analysis and to Maureen Epp for her assistance in proofreading the manuscript. The authors are grateful to M. Palanisamy and V. Vediyappan from Development of Humane Action (DHAN) Foundation, India for providing logistical support during the fieldwork. The authors are also thankful to M. Gouda and K. Shivasankar for their enumeration and translation support during the fieldwork and anonymous reviewers for their valuable comments to improve the paper.

\section{Competing interests}

The authors declare that they have no competing interests.

Received: 18 June 2015 Accepted: 23 September 2015

\section{Published online: 08 October 2015}

\section{References}

1. Planning Commission of India. Data book for DCH: selected economy and social indicators (based on Economic Survey 2012-2013). New Delhi: Government of India; 2013.

2. WTO. World Trade 2010. Prospects for 2011. Geneva: World Trade Organization; 2011. p. 2011.

3. The World Bank. World development indicators database. Washington DC: The World Bank; 2014

4. Von Grebmer K, Ringler C, Rogegrant MW, Olofinbiyi T, Wiesmann D, Fritschel $\mathrm{H}$, et al. Global hunger index: the challenge of hunger: ensuring sustainable food security under land, water and energy stresses. Bonn, Washington DC, Dublin: International Food Policy Research Institute (IFPRI); 2012.

5. Foundation Naandi. Fighting hunger and malnutrition: The HUNGaMA Survey Report 2011. Hyderabad: Naandi Foundation; 2011.

6. Basu D, Basole A. An empirical investigation of the calorie consumption puzzle in India. Boston: University of Massachusetts; 2013.

7. Lerche J. Agrarian crisis and agrarian questions in India. J Agrar Change. 2011;11(1):104-18.

8. Chandrasekhar CP. The progress of 'reform' and the retrogression of agriculture. New Delhi: MACROSCAN2007; 2014 (Contract No.: September 12).

9. Mechlem K. Food security and the right to food in the discourse of the United Nations. Eur Law J. 2004;10(5):631-48.

10. Maxwell S. Food security: a post-modern perspective. Food Policy. 1996;21(2):155-70.

11. FAO. World food and agriculture situation. Rome: Food and Agriculture Organization; 1974.

12. FAO. Trade reforms and food security: conceptualizing the linkages. Rome: Food and Agriculture Organization; 2003.

13. Sen A. Poverty and famines: an essay on entitlement and deprivation. Oxford: Clarendon Press; 1981.

14. Drèze J, Sen AK. Hunger and public action. Oxford: Clarendon Press; 1989.

15. Watts MJ, Bohle HG. Hunger, famine and the space of vulnerability. GeoJournal. 1993;30(2):117-25.

16. FAO. Rome declaration on world food security and world food summit plan of action. Rome: Food and Agriculture Organization; 1996.

17. La Via Campesina. La Via Campesina: International Peasant's Movement. Jakarta: La Via Campesina: International Operative Secretariat. 2013. http://www.viacampesina.org/en/. Accessed 13 June 2013.

18. Yaro JA. Theorizing food insecurity: building a livelihood vulnerability framework for researching food insecurity. Nor Geogr Tidsskr. 2004;58(1):23-37.

19. Maxwell S, Frankenberger TR. Household food security: concepts, indicators and measurements. New York, Rome: UNICEF and IFAD; 1992.
20. FAOSTAT. FAO statistics—food supply: crops primary equivalent. Rome: Food and Agriculture Organisation of the UN (FAO); 2013 (Contract No.: November 2, 2013).

21. Briggs J. Green Revolution. In: Kitchin R, Thrift N, editors. International encyclopedia of human geography. Oxford: Elsevier; 2009. p. 634-8.

22. Shiva $\mathrm{V}$. The violence of the green revolution: third world agriculture, ecology and politics. London and New Jersey: Zed Books; 1991.

23. Fine B. Entitlement failure? Dev Change. 1997;28(4):617-47.

24. Deaton A, Drèze J. Food and nutrition in India: facts and interpretations. Econ Polit Wkly. 2009;44(7):42-65.

25. Osmani SR. The entitlement approach to famine: an assessment. Helsinki: UNU World Institute for Development Economics Research (UNU/WIDER); 1993.

26. Scoones I. Sustainable rural livelihoods: a framework for analysis. Sussex: Institute of Development Studies; 1998.

27. Ambasta P, Shankar PSV, Shah M. Two years of NREGA: the road ahead. Econ Polit Wkly. 2008;43(8):41-50.

28. Waal Ad. Famine that kills: Darfur, Sudan. Oxford: Oxford University Press; 2004.

29. Devereux S. Sen's entitlement approach: critiques and counter-critiques. Oxf Dev Stud. 2001;29(3):245-63

30. Keen D. The benefits of famine: a political economy of famine and relief in Southwestern Sudan, 1983-1989. James Currey; 2008.

31. La Via Campesina, editor. Bangalore declaration of the Via Campesina 6 October 2000. Bangalore: La Via Campesina.

32. Wittman $\mathrm{H}$. Food sovereignty: a new rights framework for food and nature? Environ Soc Adv Res. 2011;2(1):87-105.

33. Patel R. Food sovereignty: what does food sovereignty look like? J Peasant Stud. 2009;36(3):663-706.

34. Pimbert M. Towards food sovereignty: key highlights in sustainable agriculture and natural resource management. International Institute for Environment and Development; 2009.

35. Altieri MA. Agroecology, small farms, and food sovereignty. Mon Rev. 2009;61(3):102-13.

36. Menezes F. Food sovereignty: a vital requirement for food security in the context of globalization. Development. 2001;44(4):29-33.

37. Agarwal B. Food security, food sovereignty and democratic choice: addressing potential contradictions. In: Food Sovereignty: a critical dialogue_-International Conference; 14-15 September 2013. New Haven: Yale University; 2013.

38. Akram-Lodhi AH. How to build food sovereignty. In: Food sovereignty: a critical dialogue-International Conference; 14-15 September 2013; New Haven: Yale University; 2013.

39. Biswas-Diener R, Diener E. The subjective well-being of the homeless, and lessons for happiness. Soc Indic Res. 2006;76(2):185-205.

40. Gartaula HN, Visser L, Niehof A. Sociocultural dispositions and wellbeing of the women left behind: a case of migrant households in Nepal. Soc Indic Res. 2012;108(3):401-20.

41. McGregor AJ. Researching wellbeing: from concepts to methodology. WeD Working Paper 20. Bath: ESRC Research Group on Wellbeing in Developing Countries, University of Bath; 2006.

42. Carol C, Esterik PV. Food and culture: a reader. New York: Routledge; 2007.

43. Nyerges $A E$, editor. The Ecology of practice: studies of food crop production in sub-saharan West Africa. Australia, Canada, China, France: Gordon and Breach Publishers; 1997.

44. Karthikeyan M, Jena D, Patel K, Khadka K, Devkota R, Samaratunga H, et al. Baseline survey in project sites: a report as a part of revalorizing small millets in the rainfed regions of South Asia (RESMISA). India, Nepal, Sri Lanka and Canada: DHAN Foundation, Arthacharya Foundation, Local Initiatives for Biodiversity, Research and Development (LIBIRD) and Canadian Mennonite University; 2012.

45. Census of India. Provisional population totals: rural-urban distribution, Tamil Nadu. New Delhi: Office of The Registrar General and Census Commissioner, Government of India; 2011.

46. NSSO. Land and livestock holdings survey: NSS forty-eighth round. New Delhi: National Sample Survey Organization (NSSO), Ministry of Statistics and Programme Implementation, Government of India; 1992.

47. TNCSC. Public distribution system. Tamil Nadu Civil Supplies Corporation, Tamil Nadu. 2013. http://www.tncsc.tn.gov.in/html/pds.htm. Accessed 14 June 2013. 
48. Kumar P, Mruthyunjaya, Dey MM. Long-term changes in Indian food basket and nutrition. Econ Polit Wkly. 2007;42(35):3567-72.

49. Ramachandran A, Mary S, Yamuna A, Murugesan N, Snehalatha C. High prevalence of diabetes and cardiovascular risk factors associated with urbanization in India. Diabetes Care. 2008;31(5):893-8.

50. Jones AD, Shrinivas A, Bezner-Kerr R. Farm production diversity is associated with greater household dietary diversity in Malawi: findings from nationally representative data. Food Policy. 2014;46:1-12.

51. Aggarwal A. The PDS in rural Orissa: against the grain? Econ Polit Wkly. 2011;46(36):21-3.

52. Diener E. Subjective well-being. In: Diener E, editor. The science of wellbeing. Social Indicators Research Series. Netherlands: Springer; 2009. p. $11-58$.

53. Khan AU, Saluja MR. Impact of MNREGA on rural livelihoods. Tenth sustainable development conference on sustainable solutions: a spotlight on South Asian Research, Islamabad, Pakistan; 2007.

54. Kelkar G. MGNREGA: change and continuity in gender relations. J Econ Soc Dev. 2011;7(2):11-24.

55. Agarwal B. Gender and forest conservation: the impact of women's participation in community forest governance. Ecol Econ. 2009;68(11):2785-99.

56. Desai S, Benergi M. Negotiated identities: male migration and left-behind wives in India. J Popul Res. 2008;25(3):337-55.

57. Gartaula HN, Niehof A, Visser L. Feminization of agriculture as an effect of male out-migration: unexpected outcomes from Jhapa district, eastern Nepal. Int J Interdiscip Soc Sci. 2010;5(2):565-78.

58. Reddy AA. Trends in rural wage rates: whether India reached Lewis Turning Point. SSRN: Social Science Research Network; 2013. p. 2013.

59. The Hindu. Diwali bonanza for Tihar inmates: to get double wages. The Hindu. 2014. http://www.thehindu.com/news/cities/Delhi/ diwali-bonanza-for-tihar-inmates-to-get-double-wages/article6525580. ece?homepage=true. Accessed 23 Oct 2014.

60. WHO. Energy and protein requirements: report of a joint FAO/WHO/UNU expert consultation. Geneva: Wold Health Organization; 1985.

61. Little M, Humphries S, Patel K, Dewey C. Prevalence and risk factors associated with body mass index in a rural population in south India. Int J Phys Act Behav Nutr. 2015 (a manuscript prepared for submission).

62. Bernstein H. Food sovereignty: a skeptical view. In: Food sovereignty: a critical dialogue-International Conference; 14-15 September 2013. New Haven: Yale University; 2013.

63. Hasan R, Lamba S, Sen Gupta A. Growth, structural change and poverty reduction: evidence from India. Manila: Asian Development Bank 2013.

64. De Haan A. Migration in the development studies literature: has it come out of its marginality? Research Paper: United Nations University, World Institute for Development Economics Research; 2006 (Contract No.: 19).

65. Gartaula HN, Niehof A, Visser L. Shifting perceptions of food security and land in the context of labour out-migration in rural Nepal. Food Secur. 2012;4(2):181-94.

66. De Brauw A, Rozelle S. Migration and household investment in rural China. China Econ Rev. 2008;19(2):320-35.

67. Singh S, Bhogal S. Depeasantization in Punjab: status of farmers who left farming. Curr Sci. 2014;106(10):1364-8.

68. NSSO. Employment and Unemployment Situation in India 2004-05 (Part1). New Delhi: National Sample Survey Organization (NSSO), Ministry of Statistics and Programme Implementation, Government of India; 2003.

69. Ontita EG. Creativity in everyday practice: resources and livelihoods in Nyamira, Kenya [PhD Thesis]. Wageningen: Wageningen University; 2007.

70. Bernstein H. 'Changing before our very eyes': agrarian questions and the politics of land in capitalism today. J Agrar Change. 2004;4(1-2):190-225.

\section{Submit your next manuscript to BioMed Central and take full advantage of:}

- Convenient online submission

- Thorough peer review

- No space constraints or color figure charges

- Immediate publication on acceptance

- Inclusion in PubMed, CAS, Scopus and Google Scholar

- Research which is freely available for redistribution

Submit your manuscript at

www.biomedcentral.com/submit

C BioMed Central 